\title{
Mediterranean Wild Herbs As Grain Protectants ${ }^{\dagger}$
}

\author{
Nikos E. Papanikolaou 1,**, Nickolas G. Kavallieratos ${ }^{1}$, Vassilios Iliopoulos ${ }^{2}$, Epameinondas Evergetis ${ }^{2}$, Anna \\ Skourti ${ }^{1}$ and Serkos A. Haroutounian ${ }^{2}$
}

Citation: Papanikolaou, N.E.;

Kavallieratos, N.G.; Iliopoulos, V.;

Evergetis, E.; Skourti, A.;

Haroutounian, S.A. Mediterranean Wild Herbs As Grain Protectants, in Proceedings of the 1st International Electronic Conference on

Entomology, 1-15 July 2021, MDPI:

Basel, Switzerland,

doi:10.3390/IECE-10404

Published: 30 June 2021

Publisher's Note: MDPI stays neutral with regard to jurisdictional claims in published maps and institutional affiliations.

Copyright: (c) 2021 by the authors. Submitted for possible open access publication under the terms and conditions of the Creative Commons Attribution (CC BY) license (http://creativecommons.org/licenses /by/4.0/).
1 Laboratory of Agricultural Zoology and Entomology, Department of Crop Science, Agricultural University of Athens, 75 Iera Odos str., 11855, Athens, Attica, Greece; nikosp@aua.gr (N.E.P.); nick_kaval@aua.gr (N.G.K.); annaskourti@aua.gr (A.S.)

2 Laboratory of Nutritional Feeding, Department of Animal Science, School of Animal Biosciences, Agricultural University of Athens, 75 Iera Odos str., Athens, 11855, Greece; heliopoylos@hotmail.com (V.I.); epaev@aua.gr (E.E.); sehar@aua.gr (S.A.H.)

* Correspondence: nikosp@aua.gr

+ Presented at the 1st International Electronic Conference on Entomology (IECE 2021), 1-15 July 2021;

Available online: https://iece.sciforum.net/.

\begin{abstract}
In this study we explored the pesticide properties of several essential oils (EOs), yielded from aromatic plants of the Mediterranean Basin, as wheat protectants. For this purpose, laboratory bioassays were conducted with two major stored-product insect pests, the khapra beetle, Trogoderma granarium Everts (Coleoptera: Dermestidae) and the red flour beetle, Tribolium castaneum (Herbst) (Coleoptera: Tenebrionidae). Regarding T. granarium adults, the LD50 values $7 \mathrm{~d}$ after the application were 440.6, 501.3, 506.9, 530.7, 619.1, and 745.3 ppm for the Origanum majorana, Juniperus phoenicea, Laurus nobilis, Origanum vulgare ssp. hirtum, Echinophora tenuifollia ssp. sibthropiana and Citrus limon EOs, respectively. The LD50 values for T. castaneum larvae $14 \mathrm{~d}$ after the application were 416.1, 424.1, 454.5, 490.5, 539.4 and $649.4 \mathrm{ppm}$ for the C. limon, E. tenuifollia ssp. sibthropiana, O. majorana, O. vulgare ssp. hirtum, L. nobilis and J. phoenicea EOs, respectively. The generated results could be useful for the management of the target stored-product insect pests by using reduced-risk plant protection products.
\end{abstract}

Keywords: Trogoderma granarium; Tribolium castaneum; pest management; micro emulsions; stored products

\section{Introduction}

Numerous agricultural products are damaged by pests and diseases during their development and maturation in the field [1-3]. These products are stored in facilities, where gradual manipulations are taking place, such as processing, industrialization, packaging and transportation [4]. Infestations by insects, mites, fungi and rodents are particularly common in these places [3]. Stored products are infested by insect pests that cause qualitative and quantitative losses up to $10 \%$ of the world production in developed countries and more than $20 \%$ in developing countries [5].

The essential oils (EOs) of several plants are known to serve as efficient insecticides [6-8]. In Greece, sufficient quantities of various wild herbs are available for extraction. A review of the literature showed that little is known on the application of EOs as grain protectants [6-8]. In this context, it is challenging to investigate the insecticidal properties as grain protectants of EOs derived from wild herbs of the Mediterranean Basin. It is worth noting that in recent years the bioactivity of EOs from plants originated in the Mediterranean Basin has been reported, indicating their insecticidal potential $[9,10]$ Therefore, the aim of this study was to investigate the efficacy of Citrus limon, Echinophora tenuifollia ssp. sibthropiana, Juniperus phoenicea, Laurus nobilis, Origanum majorana and Origanum vulgare ssp. hirtum, commonly found in Mediterranean, as grain protectants, against two key stored-product insect pests, i.e. the khapra beetle, Trogoderma granarium 
Everts (Coleoptera: Dermestidae) and the red flour beetle, Tribolium castaneum (Herbst) (Coleoptera: Tenebrionidae).

\section{Materials and Methods}

Trogoderma granarium and T. castaneum were cultured on wheat at $30{ }^{\circ} \mathrm{C}, 65 \%$ relative humidity and continuous darkness. The EOs of C. limon, E. tenuifollia ssp. sibthropiana, J. phoenicea, L. nobilis, O. majorana and O. vulgare ssp. hirtum were tested as wheat protectants. All the EOs were formulated to micro emulsions, with food grade emulsifier [11] and were applied as wheat coating. A stock solution of EO and Tween 20 (1:1) was prepared from each plant. The EOs stock solutions were tested at the concentrations of 250, 500 and $1000 \mathrm{ppm}$, where water with $0.05 \%$ Tween 20 served as control. Sprays were performed on plates. Quantities of $0.20 \mathrm{~kg}$ of wheat were sprayed each with $1 \mathrm{~mL}$ of the test solution as thin layers. The sprayed wheat quantities were inserted separately in plastic canisters and were shaken for $10 \mathrm{~min}$ to realize the balanced distribution of the EOs on the entire wheat masses. Three subsamples of $10 \mathrm{~g}$ were obtained and placed in Petri dishes $(9 \mathrm{~cm}$ diameter, $1.5 \mathrm{~cm}$ height). The covers of the dishes bore a circular hole (1.50 $\mathrm{cm}$ diameter). The holes were covered by muslin cloth that allowed the ventilation of the inside space of the dishes. Larvae of $T$. castaneum (2-4 mm length) and adults of $T$. castaneum $(<1$ week old), were used in the experiments. The mortality of T. castaneum larvae was determined after $14 \mathrm{~d}$ of exposure, while the mortality of $T$. granarium adults was determined after $7 \mathrm{~d}$ of exposure due to short adult longevity of this species.

Mortality data obtained from the dose-response trials were subjected to probit analysis and $\mathrm{LD}_{50}$, values, i.e., the minimal inhibition dose of an $\mathrm{EO}$ to cause $50 \%$ mortality on the studied population, were estimated. The statistical analysis was conducted using Polo Plus [12].

\section{Results}

Mortality in the control treatments was low $(<5 \%)$ for both species, therefore no correction was considered necessary for the mortality values. The results of the laboratory toxicity bioassays are shown in Table 1 .

Table 1. Mean LD50 values and 95\% confidence intervals (ppm) for Trogoderma granarium adults and Tribolium castaneum larvae 7 and 14 days after application with several essential oils, respectively.

\begin{tabular}{ccc}
\hline Treatment & Trogoderma granarium & Tribolium castaneum \\
\hline Citrus limon & $745.3 \mathrm{a}$ & $416.1 \mathrm{ac}$ \\
& $(597.1-861.5)$ & $(368.6-466.4)$ \\
Juniperus phoenicea & $501.3 \mathrm{~b}$ & $649.4 \mathrm{~b}$ \\
Laurus nobilis & $(429.6-586.4)$ & $(542.4-815.9)$ \\
& $506.9 \mathrm{~b}$ & $539.4 \mathrm{abc}$ \\
Echinophora tenuifollia ssp. sibthropiana & $(447.7-574.9)$ & $(456.9-643.8)$ \\
Origanum majorana & $619.1 \mathrm{ab}$ & $424.1 \mathrm{ac}$ \\
& $(525.7-752.3)$ & $(368.4-482.5)$ \\
Origanum vulgare ssp. hirtum & $440.6 \mathrm{~b}$ & $454.5 \mathrm{ac}$ \\
& $(369.9-517.4)$ & $(396.9-517.9)$ \\
\end{tabular}

Means in the same column followed by different letters are significantly different.

For T. granarium adults, the mean LD50 values of J. phoenicea, L. nobilis and O. majorana, i.e., 501.3, 506.9, and 440.6, respectively, were significantly lower compared to $C$. limon (745.3 ppm). The mean LD50 values of E. tenuifollia ssp. sibthropiana (619.1 ppm) and $O$. vulgare ssp. hirtum (530.7 ppm) did not significantly differ in comparison to the mean LD50 values of all other EOs.

Concerning T. castaneum larvae, the mean $\mathrm{LD}_{50}$ values of $C$. limon, E. tenuifollia ssp. sibthropiana and O. majorana, i.e., 416.1, 424.1 and $454.5 \mathrm{ppm}$, respectively, were 
significantly lower compared to the mean $\mathrm{LD}_{50}$ value of $J$. phoenicea $(649.4 \mathrm{ppm})$. In addition, the mean $\mathrm{LD}_{50}$ values of J. phoenicea, L. nobilis and O. vulgare ssp. hirtum, i.e., $649.4,539.4$ and $490.5 \mathrm{ppm}$, respectively, did not significantly differ compared to the mean LD 50 values of all the other EOs.

\section{Discussion}

T. granarium is considered one of the most important quarantine insects in various countries of the world [13]. Quarantine insects have potential economic importance in an area where they are not yet present or where they are present but are not widespread and are not controlled by phytosanitary authorities [14,15]. Quarantine insects disrupt the marketing of agricultural stored products between countries and geographical areas within countries (14). In addition, T. castaneum is widely spread in agricultural and food storage worldwide [16].

The preservation of nutritional and commercial value of stored agricultural products is highly based on their protection from insect pests [3]. Our study clearly shows the effectiveness of the EOs of six Mediterranean wild herbs against two notorious storedproduct insect species. The insecticide activity of EOs as grain protectants has only recently been studied. For example, the EOs obtained from Mentha longifolia, Dysphania ambrosioides, Carlina acaulis and Pimpinella anisum were efficient against the larger grain borer, Prostephanus truncatus (Horn) (Coleoptera: Bostrychidae) and T. granarium [6]. The potential of Hazomalania voyronii essential oil-to protect wheat infestations by T. castaneum, T. confusum and Tenebrio molitor has also been highlighted [7]. Trogoderma granarium suffered high mortality after the application of EOs obtained from Ferula assa-foetida and F. gummosa [8].

We revealed that EOs can exhibit a significant range of pesticidal activities. Treatments with synthetic contact insecticides is a common practice against storedproduct insect pests [17-19]. However, food safety is linked with integrated pest management, aiming at the reduced use of synthetic pesticides [20,21]. Our results are towards this direction, as we showed that the EOs of several Mediterranean wild herbs have the potential to serve as efficient tools against the tested major stored-product insect pests.

We expect our results to have bearing on the management of these notorious storedproducts insect species. Further research on the insecticidal activity of several Mediterranean wild herbs as grain protectants will gather more information towards an efficient, eco-friendly management of several storage pests.

Author Contributions: Conceptualization, N.E.P., N.G.K., E.E. and S.A.H.; methodology, N.E.P., N.G.K., E.E. and S.A.H.; validation, N.E.P., N.G.K., V.I., E.E. and S.A.H.; formal analysis, N.E.P. and E.E.; investigation, N.E.P., V.I., E.E. and A.S.; resources, N.E.P., N.G.K. and S.A.H.; data curation, N.E.P. and E.E.; writing-original draft preparation, N.E.P., N.G.K., E.E. and S.A.H.; writingreview and editing, N.E.P., N.G.K., E.E. and S.A.H.; supervision, N.G.K.; funding acquisition, N.E.P. and N.G.K. All authors have read and agreed to the published version of the manuscript.

Funding: This research is co-financed by Greece and the European Union (European Social FundESF) through the Operational Programme "Human Resources Development, Education and Lifelong Learning" in the context of the project "Reinforcement of Postdoctoral Researchers - 2nd Cycle" (MIS-5033021), implemented by the State Scholarships Foundation (IK؟).

Institutional Review Board Statement: Not applicable.

Informed Consent Statement: Not applicable.

Data Availability Statement: Data is contained within the article.

Conflicts of Interest: The authors declare no conflict of interest. The funders had no role in the design of the study; in the collection, analyses, or interpretation of data; in the writing of the manuscript, or in the decision to publish the results. 


\section{References}

1. Leesutthiphonchai, W.; Vu, A.L.; Ah-Fong, A.M.V.; Judelson, H.S. How does Phytophthora infestans evade control efforts? Modern inside into the late blight disease. Phytopathology 2018, 108, 916-924.

2. Biondi, A.; Guedes, R.N.C.; Wan, F-H.; Desneux, N. Ecology, worldwide spread, and management of the invasive South American tomato pinworm, Tuta absoluta: past, present, and future. Annu. Rev. Entomol. 2018, 63, $239-258$.

3. Hagstrum, D.W.; Phillips T.W. Evaluation of stored-product entomology: protecting the world food supply. Annu. Rev. Entomol. 2017, 62, 379-397.

4. Hill, D.S. Pests of Storage Foodstuffs and their Control; Kluwer Academic Publishers: New York, NY, USA, 2003.

5. Mason, L.J.; McDonough, M. Biology, behavior, and ecology of stored grain and legume insects. In Stored Product Protection; Hagstrum, D.W., Phillips, T.W., Cuperus, G., Eds.; Kansas State University: Manhattan, KS, USA, 2012; pp. 7-20.

6. Kavallieratos, N.G.; Boukouvala, M.C.; Ntalli, N.; Skourti, A.; Karagianni, E.S.; Nika, E.P.; Kontodimas, D.C.; Cappellacci, L.; Petrelli, R.; Cianfaglione, K.; Morshedloo, M.R.; Tapondjou, L.A.; Rakotosaona, R.; Maggi, F.; Benelli, G. Effectiveness of eight essential oils against two key stored-product beetles, Prostephanus truncatus (Horn) and Trogoderma granarium Everts. Food Chem. Toxicol. 2020, 139, 111255.

7. Kavallieratos, N.G.; Nika, E.P.; Skourti, A.; Ntalli, N.; Boukouvala, M.C.; Ntalaka, C.T.; Maggi, F.; Rakotosaona, R.; Cespi, M.; Perinelli, D.R.; Canale, A.; Bonacucina, G.; Benelli, G. Developing a Hazomalania voyronii essential oil nanoemulsion for the ecofriendly management of Tribolium confusum, Tribolium castaneum and Tenebrio molitor larvae and adults on stored wheat. Molecules 2021, 26, 1812.

8. Pavela, R.; Morshedloo, M.R.; Lupidi, G.; Carolla, G.; Barboni, L.; Quassinti, L.; Bramucci, M.; Vitali, L.A.; Petrelli, D.; Kavallieratos, N.G.; Boukouvala, M.C.; Ntalli, N.; Kontodimas, D.C.; Maggi, F.; Canale, A.; Benelli, G. The volatile oils from the oleo-gum-resins of Ferula assa-foetida and Ferula gummosa: a comprehensive investigation of their insecticidal activity and ecotoxicological effects. Food Chem. Toxicol 2020, 140, 111312.

9. Pavela, R.; Maggi, F.; Lupidi, G.l Vianfaglione, K.; Dauvergne, X.; Bruno, M.; Nenelli, G. Efficacy of sea fennel (Crithmum maritimum L., Apiaceae) essential oils against Culex quinquefasciatus Say and Spodoptera littoralis (Boisd.). Ind. Crops Prod. 2017, 109, 603-610.

10. Badalamenti, N.; Ilardi, V.; Bruno, M.; Pavela, R.; Boukouvala, M.C.; Kavallieratos, N.G.; Maggi, F.; Canale, A.; Benelli, G. Chemical composition and broad-spectrum insecticidal activity of the flower essential oil from an ancient Sicilian food plant, Ridolfia segetum. Agriculture 2021, 11, 304.

11. Evergetis, E.; Michaelakis, A.; Papachristos, D.P.; Badieritakis, E.; Kapsaski Kanelli, V.N.; Haroutounian, S.A. Seasonal variation and bioactivity fluctuation of two Juniperus sp. essential oils against Aedes (Stegomyia) albopictus (Skuse 1894). Parasitol. Res. 2016, 6, 2175-2183.

12. LeOra Software. Polo Plus 1.0 Probit and Logit Analysis. 2002-2014, Petaluma, CA.

13. Kavallieratos, N.G.; Athanassiou, C.G.; Guedes, R.N.C.; Drempela, J.D.; Boukouvala, M.C. Invader competition with local competitors: displacement or co-existence among the invasive khapra beetle, Trogoderma granarium Everts (Coleoptera: Dermestidae), and two other major stored-grain beetles? Front. Plant Sci. 2017, 8, 1837.

14. Myers, S.W.; Hagstrum, D.W. Quarantine. In Stored Product Protection; Hagstrum, D.W., Phillips, T.W., Cuperus, G., Eds.; Kansas State University: Manhattan, KS, USA, 2012; pp. 297-304.

15. Follett, P. A.; Neven, L.G.; Current trends in quarantine entomology. Annu. Rev. Entomol. 2006, 51, 359-85.

16. Aitken, A.D. Insect Travelers, I: Coleoptera. Technical Bulletin 31; HMSO: London, UK, 1975.

17. Skourti, A.; Kavallieratos, N.G.; Papanikolaou, N.E. How is fitness of Tribolium castaneum (Herbst) (Coleoptera: Tenebrionidae) affected when different developmental stages are exposed to chlorfenapyr? Insects 2020, 11, 542.

18. Skourti, A.; Kavallieratos, N.G.; Papanikolaou, N.E. Exposure of Tribolium castaneum (Herbst) females to pyrimiphos-methyl alters the fitness of their progeny. Environ. Sci. Poll. Res. 2021, 7, 7893-7900.

19. Kavallieratos, N.G.; Athanassiou, C.G.; Barda, M.S.; Boukouvala, M.C.; Efficacy of five insecticides for the control of Trogoderma granarium Everts (Coleoptera: Dermestidae) larvae on concrete. J. Stored Prod. Res. 2016, 66, 18-24.

20. Campbell, J.F.; Perez-Mendoza, J.; Weier, J. Insect pest management decisions in food processing facilities. In Stored Product Protection; Hagstrum, D.W., Phillips, T.W., Cuperus, G., Eds.; Kansas State University: Manhattan, KS, USA, 2012 ; pp. $219-233$.

21. Abrol, D.P.; Shankar, U. Pesticides, food safety and integrated pest management. In Integrated Pest Management; Pimentel, D., Peshin, R., Eds.; Springer; Dordrecht, 2014; pp. 167-199. 